УДК 353:001.82

DOI https://doi.org/10.32836/2310-9653-2020-3.2

\begin{abstract}
Т. А. Крушельницька, доктор наук з державного управління, доцент, професор кафедри економіки та регіональної економічної політики Дніпропетровського регіонального інституту державного управління Національної академії державного управління при Президентові України
\end{abstract}

С. В. Корнієвський, кандидат наук з державного управління, спеціаліст департаменту економічного розвитку Дніпропетровської облдержадміністрації

\title{
СТРУКТУРНО-ФУНКЦІОНАЛЬНА МОДЕЛЬ РЕГІОНАЛЬНОГО СИСТЕМНОГО УТВОРЕННЯ В МЕТОДОЛОГІї ДОСЛІДЖЕННЯ ПУБЛІЧНОГО УПРАВЛІННЯ
}

У статті наголошується, щчо для наукового розуміння і теоретичної експлікаиії складного, багатогранного і багатофакторного проиесу публічного управління сталого розвитку регіону є доиільним застосування методів моделювання, які є визнаними методами оцінок характеристик складних систем, щчо використовуються для прийняття рімень у різних сферах публічного управління.

Метою статті є виокремлення методу моделювання в методології дослідження публічного управління регіонального розвитку та розроблення структурно-функціональної моделі регіонального системного утворення.

Автори зазначають, що моделі в державному управлінні - ие засіб дослідження явищ і проиесів у державному управлінні на основі заміщення реального об'єкта його аналогами, умовними образами, тобто моделями. У гносеологічному сенсі моделі, як метод пізнання, мають властивість екстраполяиї ретроспективних закономірностей функціонування об'єкта дослідження на перспективні тенденції. Така властивість дозволяє поєднувати їх теоретичне і прикладне застосування.

Згідно з поглядом авторів, процесу моделювання публічного управління регіональним розвитком передує аналіз соціально-економічного розвитку регіону. Запропонована послідовність зазначеного аналізу, який складається з чотирьох етапів та включає теоретичний і прикладний (практичний) блоки.

Надана структурно-функиіональна модель регіонального системного утворення, структуру якого можна представити у вигляді пов'язаних між собою управлінської, економічної, соціальної та екологічної підсистем, кожна з них має власну мету та відповідні з нею функиії.

Модель може використовуватися органами регіонального управління для: аналізу поточного стану регіону; з'ясування ефективності їі функиіонування (порівняно з попередньою моделлю стану регіону); виявлення потенційних можливостей розвитку регіону та планування на иій основі можливих напрямів його розвитку (на основі з'ясування переваг $і$ недоліків); обтрунтування вибору та впровадження ефективних методів розвитку регіону тощо.

Ключові слова: публічне управління, методологія, модель, регіональне системне утворення, сталий розвиток, структурно-функиіональна модель.

T. A. Krushelnytska, S. V. Korniievskyi. Structural-functional model of regional system formation in the methodology of research of public governance

The article emphasizes that for scientific understanding and theoretical explication of complex, multifaceted and multifactorial process of public management of sustainable development of the region it is advisable to use modeling methods, which are recognized methods for assessing the characteristics of complex systems used for decision making in various areas of public administration.

The aim of the article is to single out the method of modeling in the methodology of research of public administration of regional development and development of structural-functional model of regional system formation.

The authors note that models in public administration are a means of studying phenomena and processes in public administration on the basis of replacing a real object with its analogues, conditional images, ie models. In the epistemological sense, models, as a method of cognition, have the property of extrapolating retrospective patterns of functioning of the object of study to promising trends. This property allows you to combine their theoretical and applied applications.

According to the authors, the process of modeling public management of regional development is preceded by an analysis of socio-economic development of the region. The sequence of the specified analysis which consists of four stages and includes theoretical and applied (practical) blocks is offered.

The structural-functional model of regional system formation is given, the structure of which can be represented in the form of interconnected administrative, economic, social and ecological subsystems, each of them has its own purpose and corresponding functions.

The model can be used by regional authorities for: analysis of the current state of the region; finding out the effectiveness of its functioning (compared to the previous model of the region); identification of potential opportunities for the development of the region and planning on this basis of possible directions of its development (based on the identification of advantages and disadvantages); substantiation of the choice and implementation of effective methods of development of the region, etc.

Key words: public administration, methodology, model, regional system formation, sustainable development, structuralfunctional model.

() Т. А. Крушельницька, С. В. Корнісвський, 2020 
Постановка проблеми. У світі, який все більше глобалізується, перед публічним управлінням, особливо в умовах кризи, стоять такі суперечливі завдання: з одного боку, це зближення національних економік і входження у світовий економіко-соціальний простір, а з іншого - розвиток окремих регіонів. Політика економічного розвитку провідних країн світу протягом останніх десятиліть враховувала виклики глобалізації і сприяння розвитку регіонів. Вона опиралась на моделі, які формуються а на базі досягнень матеріально-технічного виробництва, забезпечення збереження навколишнього середовища та стала фактором успіху розвитку країн Свропи й Америки. Для ретрансляції цього досвіду та формування адекватних національних практик вітчизняні науковці схиляються до думки про необхідність принципових змін у підходах до побудови моделей регіонального розвитку, які б враховували суперечності глобалізації і регіоналізації й забезпечували регіонам не лише спроможність протистояння кризовим явищам, як, наприклад, пандемія, але й сприяли їх стійкому сталому розвитку.

Вивчення соціальних та економічних процесів, які відбуваються в регіонах, спирається на досить широке коло методів і способів, якими активно користуються як науковці, так і практичні фахівці публічного управління. Зміст цих загальних і спеціальних методів зводиться до того, що дослідження регіонального розвитку, міжрегіональних зв'язків, а також конструювання їх оптимальних параметрів базується на системному аналізі явищ і процесів. Водночас моделювання $є$ універсальним методом пізнання, тож для наукового розуміння і теоретичної експлікації складного, багатогранного і багатофакторного процесу публічного управління сталого розвитку регіону є доцільним застосування методів моделювання [6]. Отже, узагальнення методології дослідження публічного управління регіонального розвитку, виокремлення серед основних методів дослідження моделювання та розробки структурно-функціональної моделі регіонального системного утворення набувають особливої актуальності в умовах вирішення глобальних і локальних суперечностей та викликів задля досягнення Цілей сталого розвитку (далі - ЦСР).

Аналіз останніх досліджень і публікацій за напрямом дослідження показує, що науковці приділяють значну увагу методології публічного управління. Такі вчені, як В. Бакуменко, А. Краснейчук, С. Серьогін, Ю. Сурмін та ін., заклали й розвивали основи методології публічного управління, яка дозволяє забезпечити розв'язання багатьох проблем, що стоять перед дослідженням теорії і практики публічного управління розвитку регіонів.

Методологічний рівень пізнання визначає концептуальний вектор спрямування розвитку державного управління і забезпечується методологічним інструментарієм, який має враховувати загально цивілізаційні й національні тенденції. Виходячи із цього, роль методології публічного управління зводиться до забезпечення процесу дослідження, структуруючи його й спрямовуючи до заданого результату за допомогою певних методів пізнання. Серед цих методів вирізняється метод моделювання, який є визнаним методом оцінок характеристик складних систем, що використовуються для прийняття рішень у різних сферах публічного управління. Так, Т.В. Кузняковою [4] визначено сутність, зміст, значення моделювання як аналітичного методу в державному управлінні. В. Ковальчук [2], розглядаючи особливості соціальних систем, зосереджує науковий пошук на соціальному моделюванні, формує теоретичну модель державного цілепокладання, що опираються на імперативи сталого розвитку. У роботі С. Горблюк [1] запропоновано структурно-функціональну модель регіональної інноваційної системи як інструменту, що дає змогу наглядно представити усі елементи, їх взаємозв'язки, ресурсне забезпечення інноваційного процесу, умови зовнішнього середовища тощо. Автором обгрунтовано доцільність їі використання органами регіонального управління для поліпшення стану регіональної інноваційної системи.

У монографічному дослідженні А. Сухорукова та Ю. Харазішвілі [9] на основі узагальнення теорії та практики регіональної економіки надано характеристику регіональних соціо-еколого-економічних систем як об'єкта моделювання та прогнозування; розроблено новий підхід до формування методологічного базису системного моделювання, прогнозування та діагностики соціально-економічного розвитку регіонів України. Здійснено моделювання та прогнозування з метою виявлення найбільш актуальних проблем і визначення на цій основі головних напрямів розвитку регіонів в умовах реалізації ЦСР.

Але, незважаючи на широку наукову увагу до методології публічного управління, сукупності методів i, зокрема, моделювання, залишається недостатньо розглянутими питання формування структурно-функціональних моделей дослідження регіонального розвитку на основі сучасних уявлень про діяльність у зазначеній сфері та з урахуванням глобальних і локальних суперечностей та викликів.

Мета статті - виокремити метод моделювання в методології дослідження публічного управління регіонального розвитку та розробити структурно-функціональну модель регіонального системного утворення.

Виклад основного матеріалу дослідження 3 повним обгрунтуванням отриманих наукових результатів. Моделювання як метод пізнання - це суто філософське поняття, а також специфічний метод, застосовуваний для цілей аналізу та синтезу систем управління. Це особливий пізнавальний прийом, коли суб'єкт замість безпосереднього дослідження об’єкта пізнання обирає (створює) схожий допоміжний об'єкт - образ (модель), досліджує його, а отримані нові знання автоматично переносить на об'єкт-оригінал. Процес моделювання припускає використання різних загально логічних методів, що дає змогу досить обгрунтовано зарахувати метод моделювання до класу синтетичних загальнонаукових методів пізнання [9, с. 82]. 
Метод моделювання є складовою частиною методології інформаційно-аналітичної діяльності у публічному управлінні, яка допомагає розв'язувати комплекс проблем, що існують в управлінні державою та її інститутами. Моделювання (у широкому сенсі) є основним методом досліджень у всіх галузях знань і науково обгрунтованим методом оцінок характеристик складних систем, що використовуються для прийняття рішень у різних сферах державного управління. Моделі у державному управлінні - це засіб дослідження явищ і процесів у державному управлінні на основі заміщення реального об’єкта його аналогами, умовними образами, тобто моделями. У гносеологічному сенсі моделі, як метод пізнання, мають властивість екстраполяції ретроспективних закономірностей функціонування об’єкта дослідження на перспективні тенденції. Така властивість дозволяє поєднувати їх теоретичне і прикладне застосування.

Існує декілька підходів до класифікації моделей. Так, за формою вираження моделі Ю. Сурмін, В. Купрійчук, К. Паригіна вирізняють такі види моделей: фізичні (матеріальними предметами), символічні (зокрема, словесними та математичними описами тощо), іконічні (зокрема рисунками, діаграмами, таблицями тощо), а також змішані [8].

Т. Кузнякова вирізняє такі види моделювання:

- концептуальне моделювання, за якого сукупність вже відомих фактів або подань щодо досліджуваного об’єкта або системи тлумачиться за допомогою деяких спеціальних знаків, символів, операцій над ними або за допомогою природної або штучної мов;

- математичне (логіко-математичне) моделювання, яке здійснюється засобами математики логіки;

- імітаційне (програмне) моделювання, за якого логіко-математична модель досліджуваного об'єкта є алгоритмом функціонування об'єкта, реалізованим у вигляді програмного комплексу для комп'ютера;

- структурно-функціональне моделювання, за якого моделями є схеми (блок-схеми), графіки, креслення, діаграми, таблиці, малюнки, доповнені спеціальними правилами їх об'єднання та перетворення;

- фізичне моделювання, за якого модель і модельований об'єкт є реальними об'єктами;

- комп'ютерне (обчислювальне) моделювання, яке проводиться засобами комп'ютерних технологій (засобами обчислювальної техніки).

Наведені види моделювання, зазначає Т. Кузнякова, не є взаємовиключними і можуть застосовуватися при дослідженні складних об'єктів або окремо, або в деякій комбінації [4].

Так, В. Ковальчук зазначає, що у складній і багатогранній теоретико-методологічній конструкції дослідження регіонального розвитку важливе місце належить розробці теоретичних моделей, оскільки модель являє собою абстрактну форму відносин між соціальними феноменами, не обов'язково точно представляє реальний соціальний світ, однак спрощує і полегшує розуміння та інтерпретацію його основних соціальних механізмів і взаємодій [2]. Теоретичні моделі відкривають широкий простір для пошуку залежності між різними змінними, що характеризують даний об'єкт, і дозволяють виявити найбільш значущі чинники його функціонування і розвитку чи, навпаки, занепаду. Саме цим пояснюється науково-пізнавальна, евристична значимість застосування методу моделювання в процесі дослідження публічного управління регіонального розвитку. Сконструйована в саме такому методологічному ключі модель публічного управління сталим соціально-економічним розвитком регіонів повинна, на переконання науковця, включати дві нерозривні і взаємодіючі частини [2]. Дійсно, у теоретичному плані модель публічного управління сталим розвитком регіонів базується на парадигмі соціальної еволюції. Вона включає систему взаємопов'язаних вимог (імперативів) до національної системи економіки, ії структури, пропорціям і тенденціям розвитку. Більше того, поставлена мета публічного управління сталим розвитком регіонів визначає організаційно-функціональну побудову органів державної влади й органів місцевого самоврядування та їх взаємодію з політичною, соціокультурною системою, приватними структурами, громадським сектором, навколишнім середовищем для забезпечення екозахисного відтворення до благодійних умов для людини, задоволення потреб нинішнього і майбутніх поколінь.

Щодо дослідження прикладних аспектів публічного управління регіонального розвитку найчастіше використовують моделі регіонального аналізу, які поділяють на такі групи, як моделі економічної бази, економетричні моделі, системи спільних рівнянь тощо.

Моделі економічної бази були одними з перших у регіональних дослідженнях, вони засновані на припущенні, що економіка регіону умовно поділена на два виробничі сектори відповідно до ринків збуту їх товарів: базовий сектор (ринки збуту за межами регіону) та обслуговуючий сектор (всередині цього регіону). Їх основною перевагою є те, що вони дозволяють оцінювати загальний вплив зовнішніх умов на регіональний ринок.

Економетричні моделі, за допомогою яких виявляють і доводять кількісно-якісні економічні взаємозв’язки, умовно поділяють на прості та системи спільних рівнянь. Прості складаються з групи регресивних рівнянь, що пов’язують загальнонаціональні і регіональні змінні.

У моделях системи спільних рівнянь враховується багаторівневий взаємозв'язок між окремими рівняннями та внутрішніми змінними кожного з них, наприклад, моделі «витрати - випуск» тощо. Ці моделі доволі часто, особливо у практиці західних дослідників, представляють як графічні зображення що забезпечує наочність 
демонстрації взаємозв'язків певних соціально-економічних чи інших явищ, наприклад, попиту та пропозиції та ефектів, що при цьому виникають.

Перелік дослідних моделей для їх застосування на різних рівнях регіональної таксономії в залежності від масштабності класифікаційних одиниць можна звести до трьох груп, це:

I. Моделі окремого регіону: а) модель міжгалузевих матеріальних зв’язків; б) модель міжгалузевих залежностей цін і доданої вартості; в) міжгалузева залежність кінцевого попиту та доданої вартості; г) міжгалузеві моделі регіону з відкритими зовнішніми зв'язками; д) оптимізаційні моделі; є) регіональні економетричні моделі; е) укрупнені моделі функціонування економіки регіону.

II. Моделі розміщення: а) моделі транспортування вантажів; б) моделі розміщення виробництва; в) моделі міграції населення тощо.

III. Міжрегіональні моделі національної економіки: а) міжрегіональний міжгалузевий баланс; б) оптимізаційні міжрегіональні моделі; в) модель економічної взаємодії регіонів. [6, с. 51-55].

Процесу моделювання публічного управління регіональним розвитком в умовах глобальних і локальних викликів передує аналіз соціально-економічного розвитку регіону, який складається з низки етапів і включає в себе теоретичну й прикладну складові. Послідовність аналізу соціально-економічного сталого розвитку регіону, узагальнена нами на рисунку 1 , iї складено на основі [7]. Зазначимо, що ми виокремили теоретичний i прикладний (практичний) блоки в аналізі, хоча такий поділ є доволі умовним, оскільки кожен $з$ етапів містить більшу чи меншу частку теоретичних узагальнень і фактологічних матеріалів.

Це такі етапи: перший - аналіз механізму регіонального розвитку, теоретичний аспект; другий - аналіз специфіки соціально-економічного розвитку окремих регіонів, прикладний, фактологічний аспект; третій аналіз організаційно-функціональної специфіки розвитку окремих регіонів, прикладний, інституційний аспект; четвертий - аналіз організаційно-функціональної специфіки розвитку окремих регіонів, прикладний, верифікаційний аспект.

Наведена етапізація процесу аналізу соціально-економічного розвитку регіону дозволяє здійснити моделювання публічного управління сталим розвитком регіонів, яка буде визначати спосіб організації і функціонування всіх структурних компонентів суспільства - економіки, політики, соціальної сфери і культури - в напрямку досягнення стратегічних цілей, приведення в цьому контексті в дію системи управління та іiї соціально-політичних механізмів.

Основними компонентами сталогорозвиткуєсоціальна, економічна та екологічна сфери, стабільний, збалансований і взаємнопідтримуючий розвиток яких орієнтовано на забезпечення високої якості життя та формування гармонійної,

\section{Периий етап}

Аналіз механізму регіонального розвитку, теоретичний аспект. На цьому етапі здійснюється визначення загально-теоретичних характеристик розвитку регіонів, узагальнюються характеристики механізму регіонального розвитку, вивчаються загальнотеоретичні підходи, прийнята наукова парадигма, принципи публічного управління. Також визначається місце регіону на глобальному, національному й локальному рівнях, з'ясовуються загальні для всіх регіонів як позитивні тенденції, так недоліки $\mathrm{i}$ диспропорції розвитку, так звані, «регіональні хвороби», притаманні для всіх регіонів а також, варіативність їх поширення і масштаб впливу, це дозволяє сформулювати мету публічного управління сталим розвитком регіону.

\section{L}

\section{Другий етап}

Аналіз специфіки соціально-економічного розвитку окремих регіонів, прикладний, фактологічний аспект. Передбачає аналіз статистикофактологічих матеріалів щодо рівня економічного і соціального розвитку певного регіону - об’єкта дослідження, до них належать: валовий регіональний продукт, темп економічного зростання; наявність/відсутність історичних традицій і гнучкість до сприйняття сучасних тенденцій, характер мультиплікативного процесу тощо. Розрахунок економічних показників, з'ясування тенденцій розвитку об’єкта, визначення факторів, що впливають на цей процес, аналіз ресурсного потенціалу тощо дають можливість визначити місце даного регіону як об'єкта управління в загальній структурі державної соціально-економічної системи.

\section{Tpemiŭ eman}

Аналіз організаційно-функціональної специфіки розвитку окремих регіонів, прикладний, інституційний аспект. Передбачає визначення інституційних характеристик розвитку конкретного регіону: історичні традиції, стиль державноуправлінської діяльності, суб'єкт-обє'ктний склад публічного управління сталим регіональним розвитком, виокремлення підсистем сталого розвитку, організаційнофункціональні особливості, система ресурсного забезпечення. Попередні два етапи дають можливість поглянути на конкретний регіон, так би мовити, «згори». На цьому ж етапі проводиться системний аналіз окремого регіону, вивчається мережа ієрархічногетерархічних зв'язків тощо, це дозволяє виявити та обгрунтувати вибір пріоритетів розвитку з урахуванням глобального, національного й локального рівнів впливу регіону.

\section{एᄂ}

\section{Yетвертий етап}

Аналіз організаційно-функціональної специфіки розвитку окремих регіонів, прикладний, верифікаційний аспект. Передбачає розробку організаційнофункціональної моделі сталого розвитку регіону, визначається коло компетенцій інститутів публічної влади щодо іії верифікації, узгоджуються їх функції, обов'язки і відповідальність, формулюються задачі й розробляються механізми і план дій тощо.

Цей етап також передбачає коригування й уточнення, для цього визначаються нові фактори та явища. Якщо такі визначені, то для перевірки об'єктивності і правильності отриманих результатів необхідним буде повернення до третього етапу. Як правило, таких ітерацій може бути декілька.

Рис. 1. Етапи аналізу соціально-економічного розвитку регіону 
фізично здорової та духовно зрілої особистості, що веде активний спосіб життя [2]. Враховуючи наведене, об’єктом політики сталого розвитку регіону стає регіональне системне утворення, структуру якого можна представити у вигляді пов'язаних між собою управлінської, економічної, соціальної та екологічної підсистем. Кожна $з$ них має власну мету та відповідні з нею функції.

Для економічної підсистеми головною метою є досягнення найвищого рівня добробуту мешканців регіону, а функцією - забезпечення темпів щорічного економічного зростання протягом певного періоду та створення економічного фундаменту для всіх інших підсистем. Для соціальної підсистеми головною метою є створення умов для формування в регіоні безпечного соціального середовища для людей, функцією - утвердження дійових механізмів соціального життєзабезпечення людини. Метою екологічної підсистеми є формування екологічно безпечного природного середовища для життя і здоров'я населення регіону. Функція цієї підсистеми полягає у впровадження екологічно збалансованої системи природокористування та збереження природних регіональних екосистем у поліпшенні екологічної ситуації в регіоні а також підвищення рівня екологічної безпеки, досягнення безпечного для здоров'я людини стану навколишнього природного середовища.

Двигуном досягнення цілей зазначених підсистем регіону стає управлінська підсистема [5, с. 121-123]. Метою управлінської підсистеми на рівні регіону є організаційно-функціональне забезпечення соціально-економічного розвитку регіону, екологічної безпеки та реалізації державної політики щодо ЦСР. Ключовими функціями підсистеми є узгодження цілей і задач регіонального розвитку та приведення у відповідність ресурсів, необхідних для їх досягнення з використанням інструментів планування, регулювання, контролю досягнення цілей тощо.

Управлінська підсистема має властивості, що дозволяють їй агрегувати не тільки елементи підсистем регіонального системного утворення, а й зовнішнього середовища, стримувати негативні впливи, запускаючи механізми самоорганізації, і відповідними мірами задавати напрямки розвитку. Визначення управлінської підсистеми як провідної в регіональному системному утворенні визначається і тим, що інструментарій, який використовується в ній для реалізації функцій управління, включає ендогенні фактори регіонального системного утворення. Саме вони повинні створювати нормативно-правове поле формування і реалізації економічної політики 3 діями місцевих, регіональних і державних органів влади [3]. Оскільки регіональне системне утворення є відкритою системою, що функціонує у визначеній частині зовнішнього середовища, то воно повсякчас перебуває під впливом зовнішніх умов та чинників (особливості нормативно-правового регулювання регіонального розвитку, державної регіональної політики, макроекономічних факторів та чинників політичної стабільності тощо). Серед зазначених умов та чинників важливе місце посідають вплив соціально-політичних проблем на економічний розвиток регіонів, що особливо загострюються в період виборів; непрозорість формування регіонального бюджету, відсутність узгодження міжбюджетних трансфертів соціального спрямування і позабюджетних коштів, призначених для регіонів тощо. Даються взнаки й негативний вплив олігархічних еліт на формування економічної політики розвитку регіонів.

Вплив на соціальну сферу характеризується неповними зайнятістю та безробіттям, руйнуванням соціальної інфраструктури, зниженням реальних доходів значної частини населення, відставанням компенсаційних заходів з індексації заробітної плати та соціальних виплат від зростання споживчих цін, наданням пільг і соціальних виплат за відомчою ознакою, без урахування реального матеріального становища різних верств населення та їхніх можливостей забезпечити свій добробут, поширення соціального утриманства в суспільстві та зменшення можливості надання допомоги тим, хто їі справді потребує тощо.

В екологічній сфері вплив зовнішнього середовища характеризується дуже високим рівнем техногенного навантаження на природне середовище в Україні, який перевищує аналогічний показник розвинутих держав у 4-5 разів і, водночас, використанням застарілих технологій та обладнання, високою концентрацією потенційно небезпечних об'єктів, нераціональним використанням природних і людських ресурсів, ресурсоємністю кінцевого національного продукту в середньому втричі перевищує світовий рівень.

На тлі цього структурно-функціональне моделювання процесів розвитку конкретного регіону може допомогти не лише ідентифікувати основних учасників у іiі чотирьох підсистемах, а також встановити якість їх взаємозв'язків та взаємодії. Ці взаємозв'язки та взаємодії визначають стан системи, вони можуть бути сильними і слабкими, регулярними та нерегулярними, забезпечувати регіональний розвиток.

Вищенаведене дозволяє нами побудувати структурно-функціональну модель регіонального системного утворення, яка представлена на рисунку 2. Для врахування специфіки конкретного регіону потрібно формувати окрему модель на основі реальної ситуації. Так, для розробки ефективної політики регіонального розвитку в кожному регіоні доцільно розробляти свою структурно-функціональну модель [1]. Ця структурно-функціональна модель регіонального системного утворення $є$ аналітичним інструментом, оскільки дає змогу наглядно представити усі елементи системи, їхні взаємозв'язки, ресурсне забезпечення процесу розвитку, умови зовнішнього середовища.

Ця модель може використовуватися органами регіонального управління для: аналізу поточного стану регіону; 3'ясування ефективності іiї функціонування (порівняно з попередньою моделлю стану регіону); виявлення потенційних можливостей розвитку регіону та планування на цій основі можливих напрямів його розвитку (на основі 
3'ясування переваг і недоліків); обгрунтування вибору та впровадження ефективних методів розвитку регіону тощо.

Висновки. Таким чином, можемо зробити такі висновки:

1. Виокремлено метод моделювання в методології дослідження публічного управління регіонального розвитку та доведено, що моделі управління сталим розвитком регіонів відбивають спосіб організації i функціонування всіх структурних компонентів суспільства економіки, політики, соціальної сфери і культури - в напрямку досягнення стратегічних цілей та Цілей сталого розвитку. У гносеологічному сенсі моделі, як метод пізнання, мають властивість екстраполяції ретроспективних закономірностей функціонування об'єкта дослідження на перспективні тенденції. Така властивість дозволяє поєднувати їх теоретичне і прикладне застосування.

2. Визначено, що об’єктом політики сталого розвитку регіону є регіональне системне утворення, та запропоновано його структуру у вигляді пов'язаних між собою управлінської, економічної, соціальної та екологічної підсистем. На підставі цього визначені функція та мета кожної з підсистем.

3. Досліджено вплив зовнішнього середовища на регіональне системне утворення та запропонована структурно-функціональна модель регіонального системного утворення, яка дозволить ідентифікувати основних учасників у їі чотирьох підсистемах, а також встановити якість їхніх взаємозв’язків та взаємодії.

Перспективи подальших розвідок у даному напрямі - дослідження теоретичної сутності і структури регіонального системного утворення.

\section{Список використаних джерел:}

1. Горблюк С.А. Структурно-функціональна модель регіональної інноваційної системи. Ефективність державного управління. 2015. Вип. 45. С. 183-190.

2. Ковальчук В.Г. Моделі управління соціально-економічним розвитком регіону, держави. Актуальні проблеми державного управління. 2013. № 1. С. 194-201.

3. Корнієвський С.В. Управлінська підсистема як провідна у регіональному системному утворенні. Теорія та практика державного управління: зб. наук. пр. Харків : ХарРІ НАДУ, 2014. № 3(46). С. $72-79$.

4. Кузнякова Т.В. Моделювання як аналітичний метод у державному управлінні. Вісник Національного університету ичивільного захисту Украӥни. Серія : Державне управління. 2014. Вип. 2. С. 49-56. 
5. Месарович М. Теория иерархических многоуровневых систем / М. Месарович, Д. Мако, И. Такахара. Москва : МИР, 1973. 344 с.

6. Регіональна політика Європейського Союзу : підручник / за ред. Віктора Чужикова. Київ : КНЕУ, 2016. $495 \mathrm{c}$.

7. Стеценко Т.О. Аналіз регіональної економіки : навч. посібник. Київ : КНЕУ, 2002. 116 с.

8. Сурмін Ю.П. Моделі в державному управлінні. Енциклопедія державного управління : у 8 m. / Нац. акад. держ. упр. при Президентові України ; наук.-ред. колегія : Ю.В. Ковбасюк (голова) та ін. Київ : НАДУ, 2011. Т. 2 : Методологія державного управління / наук.-ред. колегія : Ю.П. Сурмін (співголова), П.І. Надолішній (співголова) та ін. 2011. С. 380.

9. Сухоруков А.І. Моделювання та прогнозування соціально-економічного розвитку регіонів України : монографія. Київ : НІСД, 2012. 368 с.

\section{References:}

1. Horbliuk S. A. (2015) "Strukturno-funktsionalna model rehionalnoi innovatsiinoi systemy “ [Structural and functional model of the regional innovation system], journal Efektyvnist derzhavnoho upravlinnia [Efficiency of public administration], Vol. 45, pp. 183-190 [Ukraine]

2. Kovalchuk V. H. (2013) "Modeli upravlinnia sotsialno-ekonomichnym rozvytkom rehionu, derzhavy" [Models of management of social and economic development of the region, the state], journal Aktualni problemy derzhavnoho upravlinnia [Actual problems of public administration], Vol 1, pp. 194-201 [Ukraine]

3. Korniievskyi S. V. (2014) "Upravlinska pidsystema yak providna u rehionalnomu systemnomu utvorenni" [Management subsystem as a leader in the regional system formation], journal Teoriia ta praktyka derzhavnoho upravlinnia [Theory and practice of public administration], Vol. 3 (46), pp. $72-79$ [Ukraine]

4. Kuzniakova T. V. (2014) "Modeliuvannia yak analitychnyi metod u derzhavnomu upravlinni" [Modeling as an analytical method in public administration], journal Visnyk Natsionalnoho universytetu tsyvilnoho zakhystu Ukrainy Seriia : Derzhavne upravlinnia [Bulletin of the National University of Civil Defense of Ukraine. Series: Public Administration], Vol. 2, pp. 49-56 [Ukraine]

5. Mesarovich M., Mako D., Takahara I. (1973) Teoriya ierarhicheskih mnogourovnevyih sistem [Theory of hierarchical multilevel systems], Press MIR, Moscow, 344 p. [USSR].

6. Edited by Chuzhykov V. (2016). Rehionalna polityka Yevropeiskoho Soiuzu [Regional policy of the European Union], Tutorial, Press KNEU, Kyiv, 495 p. [Ukraine]

7. Stetsenko T. O. (2002). Analiz rehionalnoi ekonomiky [Analysis of the regional economy], Tutorial, Press KNEU, Kyiv, 116 p. [Ukraine]

8. Surmin Yu. P. (2011). Modeli v derzhavnomu upravlinni [Models in public administration], Entsyklopediia derzhavnoho upravlinnia [Encyclopedia of public administration], (Vol. 2), Press NADU, Kyiv, P. 380. [Ukraine]

9. Sukhorukov A. I. and Kharazishvili Yu. M. (2012). Modeliuvannia ta prohnozuvannia sotsialno-ekonomichnoho rozvytku rehioniv Ukrainy [Modeling and forecasting of socio-economic development of the regions of Ukraine], Monograph, Press NISD, Kyiv, 368 p. [Ukraine] 